\title{
Divergent responses of soil carbon and nitrogen pools to short-term nitrogen addition between two plantations in Northeast China
}

\author{
Yedong $\mathrm{Li}^{1,2}$, Bo Wang ${ }^{3,4}$, Sen Dou ${ }^{1 *}$, Haoyue Shen ${ }^{3}$, Liyong $\mathrm{Mei}^{3}$, Yang Zhang ${ }^{3}$, Ximing Zeng ${ }^{4}$, \\ Yaya Zhang ${ }^{3}$, Yameng Pei ${ }^{3}$, Haoye Ren $^{3}$, Shimin $\mathrm{Wu}^{3 *}$ \\ (1. College of Resources and Environment, Jilin Agricultural University, Changchun 130118, China; \\ 2. Jingyue High-Tech Industrial Development Zone Division, Changchun Ecology and Environment Bureau, Changchun 130117, China; \\ 3. IER Environmental Protection Engineering Technology Co., Ltd., Shenzhen 518071, China; \\ 4. School of Urban Planning and Design, Shenzhen Graduate School, Peking University, Shenzhen 518055, China)
}

\begin{abstract}
Nitrogen (N) deposition has a profound influence on forest soil carbon $(\mathrm{C})$ and $\mathrm{N}$ pools, but there was no consensus on the responses of different $\mathrm{C}$ and $\mathrm{N}$ components in different forest types. In this study, a two-year simulated $\mathrm{N}$ deposition experiment with four levels of $\mathrm{N}\left(\mathrm{NH}_{4} \mathrm{NO}_{3}\right)$-addition treatments $\left(0,50,100\right.$, and $150 \mathrm{~kg} \mathrm{~N} / \mathrm{hm}^{2} \cdot$ a) were conducted in Larix gmelinii (LG) and Quercus mongolica (QM) plantation in Northeast China, in order to investigate the $\mathrm{C}$ and $\mathrm{N}$ pool dynamics under continuously enhanced $\mathrm{N}$ deposition. Soil organic carbon (SOC), soil total N (STN) and their active components (readily oxidizable C, ROC; dissolved organic C, DOC; microbial biomass C, MBC, dissolved organic N, DON; microbial biomass N, MBN) of the forest soil were measured monthly from May to October 2017. C and N contents in LG were observed higher than in QM. N addition had no effect on SOC and STN of LG, but significantly increased SOC and STN of $\mathrm{QM}$ at low $\mathrm{N}$ addition level. Low $\mathrm{N}$ addition generally raised active $\mathrm{C}$ components (ROC, DOC, and MBC) in both plantations, whereas high $\mathrm{N}$ addition did not significantly affect these components, or even decreased ROC in LG soil. Low $\mathrm{N}$ addition also increased STN and MBN of QM, while no significant change in STN and MBN of LG was observed. DON was directly affected by $\mathrm{N}$ addition and increased significantly with elevated $\mathrm{N}$ addition levels. The results indicated that $\mathrm{N}$ addition, especially of low rate, might enhance the $\mathrm{C}$ sequestration capacity of the forest soils and mitigate climate change.
\end{abstract}

Keywords: nitrogen deposition, forest soil, active carbon, active nitrogen

DOI: $10.25165 /$ j.ijabe.20191206.5266

Citation: Li Y D, Wang B, Dou S, Shen H Y, Mei L Y, Zhang Y, et al. Divergent responses of soil carbon and nitrogen pools to short-term nitrogen addition between two plantations in Northeast China. Int J Agric \& Biol Eng, 2019; 12(6): 82-90.

\section{Introduction}

With the rapid agricultural, industrial and urban development, human activities have released a large amount of reactive nitrogen $(\mathrm{N})$ into the atmosphere and led to a dramatic increase in global $\mathrm{N}$ deposition over the past century ${ }^{[1-3]}$. The enhancement of $\mathrm{N}$ deposition has exerted a profound impact on forest ecosystems ${ }^{[4]}$, which dominates the dynamics of the terrestrial carbon (C) cycle and thus are crucial for mitigating climate change $\mathrm{e}^{[5]}$.

The responses of forest soil $\mathrm{C}$ pools to $\mathrm{N}$ addition have been

\section{Received date: 2019-07-04 Accepted date: 2019-10-28}

Biographies: Yedong $\mathbf{L i}, \mathrm{PhD}$, research interests: soil biochemistry, Email: 4241821@qq.com; Bo Wang, MSc, research interests: ecological restoration, Email: 1801111800@pku.edu.com; Haoyue Shen, MSc, research interests: ecological restoration, Email: 85987801@qq.com; Liyong Mei, MSc, research interests: ecological restoration, Email: meilyong@vip.qq.com; Yang Zhang, $\mathrm{PhD}$, research interests: forest ecology, Email: nefu_zhy@qq.com; Ximing Zeng, PhD, research interests: forest ecology, Email: z1988simon@hotmail.com; Yaya Zhang, MSc, research interests: biogeochemistry, Email: yyzhang0040@ 163.com; Yameng Pei, MSc, research interests: forest ecology, Email: 18790552867@163.com; Haoye Ren, MSc, research interests: biogeochemistry, Email: 970879082@qq.com.

*Corresponding author: Sen Dou, PhD, Professor, research interests: soil biochemistry. College of Resources and Environment, Jilin Agricultural University, 2888 Xincheng Street, Changchun 130118, China, Tel: +86-431-84532851, Email: dousen1959@126.com; Shimin Wu, PhD, research interests: environmental sciences, ecotoxicology. Block 2, Environmental Industrial Park, 31 Makan South Road, Shenzhen 518071, China. Tel: +86-18566772909, Email: wushimin@gmail.com. explored worldwide, and variable responses have been overserved in different forest ecosystems, including being promoted ${ }^{[6-8]}$, inhibited $^{[9-11]}$, or having no effects ${ }^{[12-14]}$, which depend on the dose, timing and type of $\mathrm{N}$ additions, as well as the soil $\mathrm{N}$ status and forest type ${ }^{[15,16]}$. On the other hand, soil $\mathrm{N}$ pools also have been studied and found less affected by $\mathrm{N}$ addition ${ }^{[12,14]}$. Numerous studies have documented that enhanced $\mathrm{N}$ deposition could affect the forest soil $\mathrm{C}$ and $\mathrm{N}$ pools by influencing terrestrial ecosystem processes including plant growth, litter decomposition, soil organic matter turnover and soil respiration ${ }^{[17,18]}$. Unfortunately, due to the complexities of soil chemical properties and their interactions with soil microorganisms ${ }^{[19]}$, the corresponding mechanisms remain uncertain.

Soil organic carbon (SOC) in forest soils is the largest terrestrial C pool accounting for approximately $73 \%$ of global soil $\mathrm{C}$ pool $^{[20]}$, which can be divided into labile (or active) and recalcitrant components according to the turnover time ${ }^{[21,22]}$. Active organic $\mathrm{C}$ is easily oxidizable and mineralizable in the soils with turnover time of a few days to months, thus strongly affected by plants or microorganisms ${ }^{[23]}$. It directly gets involved in the soil biochemical processes, playing as a driving force for soil nutrient cycling ${ }^{[24]}$. Although active organic $\mathrm{C}$ makes up only a small part of SOC, it can reflect the minor changes of soils caused by environment conditions prior to $\mathrm{SOC}^{[25]}$, therefore it has been widely used as a sensitive index of soil quality ${ }^{[21]}$.

Readily oxidizable C (ROC), dissolved organic C (DOC), and microbial biomass $\mathrm{C}(\mathrm{MBC})$ are essential components of active 
organic C, which are often used to indicate SOC activity ${ }^{[26,27]}$. ROC, contributing hardly $20 \%$ of SOC, is considered an early indicator of $\mathrm{C}$ dynamics, due to its higher sensitivity to changes in soil biogeochemical properties than SOC $^{[28]}$. DOC plays a key role in soil $\mathrm{C}$ cycling by physical migration and chemical transformation $^{[29]}$, while MBC expresses soil microbial biomass which is important to control $\mathrm{C}$ and nutrient flows ${ }^{[30]}$. Similarly, dissolved organic $\mathrm{N}(\mathrm{DON})$ and microbial biomass $\mathrm{N}(\mathrm{MBN})$ are the active components of soil total $\mathrm{N}(\mathrm{STN})^{[31]}$, that are also crucial in regulating the dynamics of soil $\mathrm{C}$ and $\mathrm{N}$ pools ${ }^{[32]}$.

China currently has become one of the largest $\mathrm{N}$ deposition regions after Europe and the United States ${ }^{[33,34]}$. Since approximately $1 / 5$ of the land area in China is covered by forests ${ }^{[35]}$, understanding the responses of forests to enhanced $\mathrm{N}$ deposition will have critical implications for predicting their ecological impact in the global $\mathrm{C}$ and $\mathrm{N}$ cycle and improving China's forest management ${ }^{[16]}$. In this study, a short-term simulated $\mathrm{N}$ deposition experiment was conducted in both Dahurian larch (Larix gmelinii) and Mongolian oak (Quercus mongolica) plantations, which are key commercial species in Northeast China. Soil C and $\mathrm{N}$ components, including SOC, STN, and their active fractions (i.e. ROC, DOC, MBC, DON, and MBN) were analyzed during the growing season. The specific objectives of this research were to determine: (1) the responses of SOC and STN to different levels of $\mathrm{N}$ addition; (2) the contribution of active $\mathrm{C}$ and $\mathrm{N}$ components to the variation in soil $\mathrm{C}$ and $\mathrm{N}$ pools; (3) the correlation of soil $\mathrm{C}$ and $\mathrm{N}$ under different $\mathrm{N}$ addition treatments; (4) the differences between the two plantation species in responses to $\mathrm{N}$ addition.

\section{Materials and methods}

\subsection{Study site}

The study area is located in Jingyuetan National Forest Park, Changchun City, Jilin Province, Northeast China (125 $26^{\prime} 15^{\prime \prime} \mathrm{E}-$ $125^{\circ} 33^{\prime} 45^{\prime \prime} \mathrm{E}, 43^{\circ} 41^{\prime} 30^{\prime \prime} \mathrm{N}-43^{\circ} 49^{\prime} \mathrm{N}$; elevation 220-406 m above sea level). It has a sub-humid temperate continental monsoon climate, with mean annual temperature of $4.7^{\circ} \mathrm{C}$ and precipitation of $645.3 \mathrm{~mm}$. The area receives on average $2525.8 \mathrm{~h}$ of sunshine and 145 frost-free days annually. The soil is dark-brown forest soil which is equivalent to Humaquepts or Cryoboralfs in American Soil Taxonomy. Natural $\mathrm{N}$ deposition in this reserve is 17$21 \mathrm{~kg} \mathrm{~N} / \mathrm{hm}^{2} \cdot \mathrm{a}^{[36]}$. The plantation was established in 1962, comprised of species Pinus koraiensis, Larix gmelinii, Quercus mongolica, Populus davidiana, Pinus sylvestris, Sorbaria sorbifolia, Rubus crataegifolius, Lonicera spp., Corylus mandshurica, Acanthopanax senticosus, Paris verticillate, etc.

\subsection{Experimental design}

The N-deposition simulation experiment was initiated in May 2017 within two forest stands, Larix gmelinii (LG) and Quercus mongolica (QM), employing a method widely used in previous studies ${ }^{[37]}$. The initial stand and soil characteristics of the two forest stands are presented in Table 1 . Twelve $20 \mathrm{~m} \times 30 \mathrm{~m}$ plots with a buffer zone of $8 \mathrm{~m}$ were established in each stand. Four $\mathrm{N}$ addition treatment groups with three replicate plots for each group were established, including control (CK, $\left.0 \mathrm{~kg} \mathrm{~N} / \mathrm{hm}^{2} \cdot \mathrm{a}\right)$, low-N addition (LN, $50 \mathrm{~kg} \mathrm{~N} / \mathrm{hm}^{2} \cdot \mathrm{a}$ ), medium-N addition (MN, $100 \mathrm{~kg}$ $\left.\mathrm{N} / \mathrm{hm}^{2} \cdot \mathrm{a}\right)$, and high-N addition $\left(\mathrm{HN}, 150 \mathrm{~kg} \mathrm{~N} / \mathrm{hm}^{2} \cdot \mathrm{a}\right)$. All plots and treatments were randomly laid out. Ammonium nitrate $\left(\mathrm{NH}_{4} \mathrm{NO}_{3}\right)$ was added as the fertilizer at the end of each month from May 2016 to April 2017. For each application, $\mathrm{NH}_{4} \mathrm{NO}_{3}$ was weighed, dissolved in $2 \mathrm{~L}$ of distilled water, and sprayed evenly on the forest floor with a backpack sprayer. The control plots received $2 \mathrm{~L}$ of distilled water without $\mathrm{NH}_{4} \mathrm{NO}_{3}$ added. The air temperature and precipitation in the study area during the experiment were ranged at $-20^{\circ} \mathrm{C}-30^{\circ} \mathrm{C}$ and $0-90 \mathrm{~mm}$, respectively (Figure 1). The additional water in each plot during the experiment is only equivalent to an increase of $0.04 \mathrm{~mm}(0.006 \%)$ in annual precipitation, thus the influence of external water can be ignored.

Table 1 Stand and soil characteristics of Larix gmelinii (LG) and Quercus mongolica (QM) stands in this study

\begin{tabular}{cccccccccc}
\hline & Coverage/\% & Density $/ \mathrm{plant} \cdot \mathrm{hm}^{-2}$ & Age/a & Slope gradient $/\left(^{(}\right)$ & Average DBH $/ \mathrm{cm}$ & $\mathrm{pH}$ & Moisture/\% & $\mathrm{SOC} / \mathrm{g} \cdot \mathrm{kg}^{-1}$ & $\mathrm{STN} / \mathrm{g} \cdot \mathrm{kg}^{-1}$ \\
\hline$L G$ & 55.0 & 685 & 54.0 & 15.0 & 12.9 & $5.66 \pm 0.12$ & $24.1 \pm 3.2$ & $80.2 \pm 2.9$ & $5.85 \pm 0.30$ \\
$Q M$ & 70.0 & 951 & 54.0 & 10.0 & 16.1 & $5.52 \pm 0.15$ & $28.9 \pm 4.1$ & $51.0 \pm 1.8$ & $3.87 \pm 0.17$ \\
\hline
\end{tabular}

Note: Mean and standard error of soil properties are presented (n=3). DBH: diameter at breast height; SOC: soil organic C; STN: soil total N.

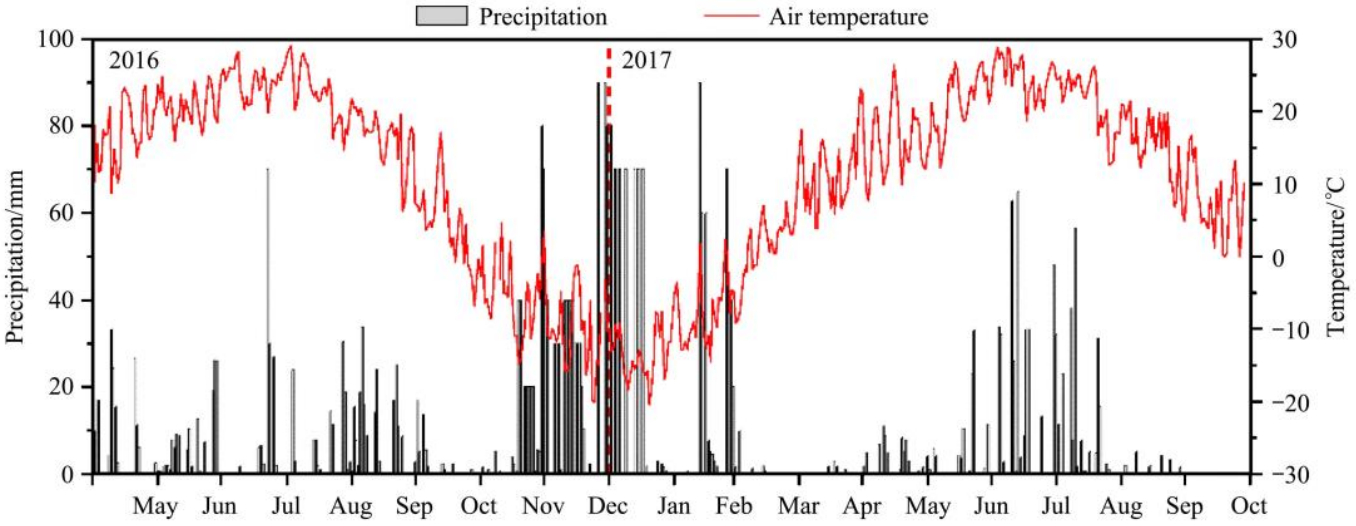

Figure 1 Seasonal air temperature and precipitation patterns in the study area from May 2016 to October 2017

\subsection{Soil sampling and chemical analysis}

Mineral soil samples at 0-10 cm depth were collected monthly from May to October in 2017. Five soil subsamples were collected randomly from each plot using a cylindrical soil auger $(\phi 2.5 \mathrm{~cm})$ and mixed to form a composite sample. The composite samples were passed through a $2 \mathrm{~mm}$ sieve to eliminate plant residues and stones. An aliquot of each composite soil sample was stored at $4{ }^{\circ} \mathrm{C}$ and analyzed within $72 \mathrm{~h}$ for DOC, DON MBC, and MBN content; the rest was air-dried and passed through a $0.25 \mathrm{~mm}$ sieve for the analysis of SOC, STN, and ROC content.

SOC and STN were measured by dry combustion with a macro elemental analyzer (Elementar Analysensysteme $\mathrm{GmbH}$, 
Germany). ROC was determined by wet oxidization with $333 \mathrm{mM}$ $\mathrm{KMnO}_{4}{ }^{[26]}$. MBC and $\mathrm{MBN}$ were determined using the chloroform-fumigation extraction method, which were calculated as the difference in extractable $\mathrm{C}$ and $\mathrm{N}$ between fumigated and non-fumigated soils, divided by $0.45^{[38]}$ and $0.54^{[39]}$, respectively. The non-fumigated $\mathrm{C}$ and $\mathrm{N}$ content were considered as DOC and DON, respectively ${ }^{[40]}$.

\subsection{Data statistical analyses}

A three-factor mixed-design analysis of variance (ANOVA) with $\mathrm{N}$ addition treatment and forest type as the between-subject effect and sampling month as the within-subject effect was used to analyze the changes in soil properties. To examine the effects of $\mathrm{N}$ addition treatment on the soil properties for each forest type, a two-factor mixed-design ANOVA with post-hoc Tukey's honestly significant difference (HSD) test was used with $\mathrm{N}$ addition treatment as the between-subject effect and sampling month as the within-subject effect. When Mauchly's test of sphericity was not fulfilled, the Greenhouse-Geisser correction was applied. A one-way ANOVA with post-hoc Tukey's HSD test was conducted to examine the effects of $\mathrm{N}$ addition on soil properties of each forest type in a certain month. Homogeneity of variances was tested using Levene's test before above ANOVAs, and the variances of all the data were homogeneous. The significant level for all tests was set at $p=0.05$. All ANOVA analyses and post-hoc tests were performed using SPSS 24.0 for Windows (IBM Corp, Armonk, NY). Redundancy analysis (RDA) was carried out using Canoco 5.0 (Microcomputer Power, Ithaca, NY, USA) to examine the interrelationships among soil properties of each forest type, $\mathrm{N}$ addition treatments, and sampling month.

\section{Results}

\subsection{Effects of $\mathbf{N}$ deposition on soil $\mathbf{C}$ components}

A significant three-way interaction was observed in all soil $\mathrm{C}$ components among $\mathrm{N}$ addition treatment, forest type, and sampling month $(p<0.01$, Table 2$)$, except for SOC $(p=0.484)$ and DOC $(p=0.117)$. SOC and all active C components (ROC, DOC, and MBC) exhibited significant monthly variations $(p<0.001$, Table 2$)$. Forest type caused a significant difference in all soil $\mathrm{C}$ components ( $p<0.01$, Table 2$)$, except for ROC/SOC $(p=0.051)$. The average SOC, ROC, DOC, and MBC concentrations of LG $(81.0 \mathrm{~g} / \mathrm{kg}$, $12.9 \mathrm{~g} / \mathrm{kg}, 65.9 \mathrm{mg} / \mathrm{kg}$, and $659 \mathrm{mg} / \mathrm{kg}$ ) were $1.51,1.41,1.27$, and 1.36 times as high as QM, respectively. The average proportions of active C components to SOC (ROC/SOC, DOC/SOC, and $\mathrm{MBC} / \mathrm{SOC})$ of $\mathrm{LG}(15.9 \%, 0.08 \%$, and $0.83 \%)$ were $0.93,0.83$, and 0.89 times the values of QM, respectively. Significant interaction of sampling month and forest was observed for all soil C components and active C component proportions $(p<0.001$, Table 2). The interaction of forest and $\mathrm{N}$ addition treatment was not significant only for $\operatorname{SOC}(p=0.380), \operatorname{MBC}(p=0.702)$, and $\mathrm{MBC} / \mathrm{SOC}(p=0.792)$, which indicated that $\mathrm{N}$ addition had similar effects on SOC and MBC.

Table 2 Results of three-factor mixed-design ANOVA on the effects of $\mathrm{N}$ addition treatment, forest type, and sampling month on soil properties

\begin{tabular}{|c|c|c|c|c|c|c|c|c|}
\hline \multirow{2}{*}{\multicolumn{2}{|c|}{ Soil Properties }} & \multicolumn{4}{|c|}{ Within-subject effects } & \multicolumn{3}{|c|}{ Between-subjects effects } \\
\hline & & Month & Month $\times \mathrm{N}$ addition & Month $\times$ Forest & Month $\times$ Forest $\times \mathrm{N}$ addition & Forest & $\mathrm{N}$ addition & Forest $\times \mathrm{N}$ addition \\
\hline \multirow{6}{*}{$\mathrm{C}$} & SOC & $<0.001$ & 0.181 & $<0.001$ & 0.484 & $<0.001$ & 0.007 & 0.380 \\
\hline & ROC & $<0.001$ & $<0.001$ & $<0.001$ & $<0.001$ & $<0.001$ & $<0.001$ & $<0.001$ \\
\hline & DOC & $<0.001$ & 0.014 & $<0.001$ & 0.117 & $<0.001$ & $<0.001$ & 0.001 \\
\hline & $\mathrm{MBC}$ & $<0.001$ & $<0.001$ & $<0.001$ & $<0.001$ & $<0.001$ & $<0.001$ & 0.702 \\
\hline & $\mathrm{DOC} / \mathrm{SOC}$ & $<0.001$ & 0.005 & $<0.001$ & 0.009 & $<0.001$ & $<0.001$ & $<0.001$ \\
\hline & $\mathrm{MBC} / \mathrm{SOC}$ & $<0.001$ & $<0.001$ & $<0.001$ & 0.003 & $<0.001$ & $<0.001$ & 0.792 \\
\hline \multirow{4}{*}{$\mathrm{N}$} & STN & $<0.001$ & 0.001 & $<0.001$ & 0.005 & $<0.001$ & 0.005 & 0.786 \\
\hline & DON & $<0.001$ & $<0.001$ & $<0.001$ & $<0.001$ & $<0.001$ & $<0.001$ & 0.001 \\
\hline & MBN & $<0.001$ & $<0.001$ & $<0.001$ & 0.001 & $<0.001$ & 0.011 & 0.671 \\
\hline & DON/STN & $<0.001$ & $<0.001$ & $<0.001$ & $<0.001$ & 0.378 & $<0.001$ & 0.063 \\
\hline \multirow{3}{*}{$\mathrm{C} / \mathrm{N}$} & SOC/STN & $<0.001$ & 0.081 & $<0.001$ & 0.036 & $<0.001$ & 0.023 & 0.053 \\
\hline & DOC/DON & $<0.001$ & $<0.001$ & $<0.001$ & $<0.001$ & $<0.001$ & $<0.001$ & 0.001 \\
\hline & $\mathrm{MBC} / \mathrm{MBN}$ & $<0.001$ & $<0.001$ & $<0.001$ & $<0.001$ & $<0.001$ & $<0.001$ & 0.577 \\
\hline
\end{tabular}

Note: $n=144$, i.e., four $\mathrm{N}$ addition levels $\times$ two forest types $\times$ six months $\times$ three repetitions. $\quad p$-values are shown.

The effects of $\mathrm{N}$ addition treatment and sampling month on the soil C components were further examined for $\mathrm{LG}$ and $\mathrm{QM}$ individually. In LG stands, $\mathrm{N}$ addition treatment had no significant effect on SOC ( $p=0.118$, Figure $2 a)$ apart from active C components $(p<0.001$, Figures $2 \mathrm{c}, 2 \mathrm{e}$, and $2 \mathrm{~g})$. The significant interaction of $\mathrm{N}$ addition and sampling month for ROC and MBC $(p<0.001$, Figures $2 \mathrm{c}$ and $2 \mathrm{~g}$ ) indicated that the effect of $\mathrm{N}$ addition varied in different months. In $\mathrm{QM}$ stands, $\mathrm{N}$ addition treatment had a significant effect on all soil $\mathrm{C}$ components $(p \leq 0.01$, Figures $2 \mathrm{~b}, 2 \mathrm{~d}, 2 \mathrm{f}$, and $2 \mathrm{~h}$ ), and no interaction of $\mathrm{N}$ addition and sampling month was found only for SOC ( $p=0.738$, Figure $2 b)$. LN led to a significant increase in only active $\mathrm{C}$ components (ROC, DOC, and $\mathrm{MBC}$ ) of $\mathrm{LG}$ (Figures $2 \mathrm{c}, 2 \mathrm{e}$, and $2 \mathrm{~g}$ ), but all soil $\mathrm{C}$ components of QM (Figures $2 \mathrm{~b}, 2 \mathrm{~d}, 2 \mathrm{f}$, and $2 \mathrm{~h}$ ). $\quad$ MN raised only ROC and DOC of QM (Figures 2d and 2f), but suppressed ROC of LG (Figure 2c). HN caused a significant decrease in ROC of LG (Figure 2c).

All soil C components fluctuated with sampling month ( $p<0.001$, Figure 2). SOC declined from June to August and increased afterward in both LG and QM stands (Figures 2a and 2b). ROC of LG and QM minimized in July and August, respectively (Figures 2c and 2d). DOC of both stands showed a global maximum point in May and a secondary maximum point in August (Figures 2e and 2f). MBC started an increase in May and peaked in September (Figures $2 \mathrm{~g}$ and $2 \mathrm{~h}$ ); however, MBC of LG showed a decrease from June to July (Figure $2 \mathrm{~g}$ ). 


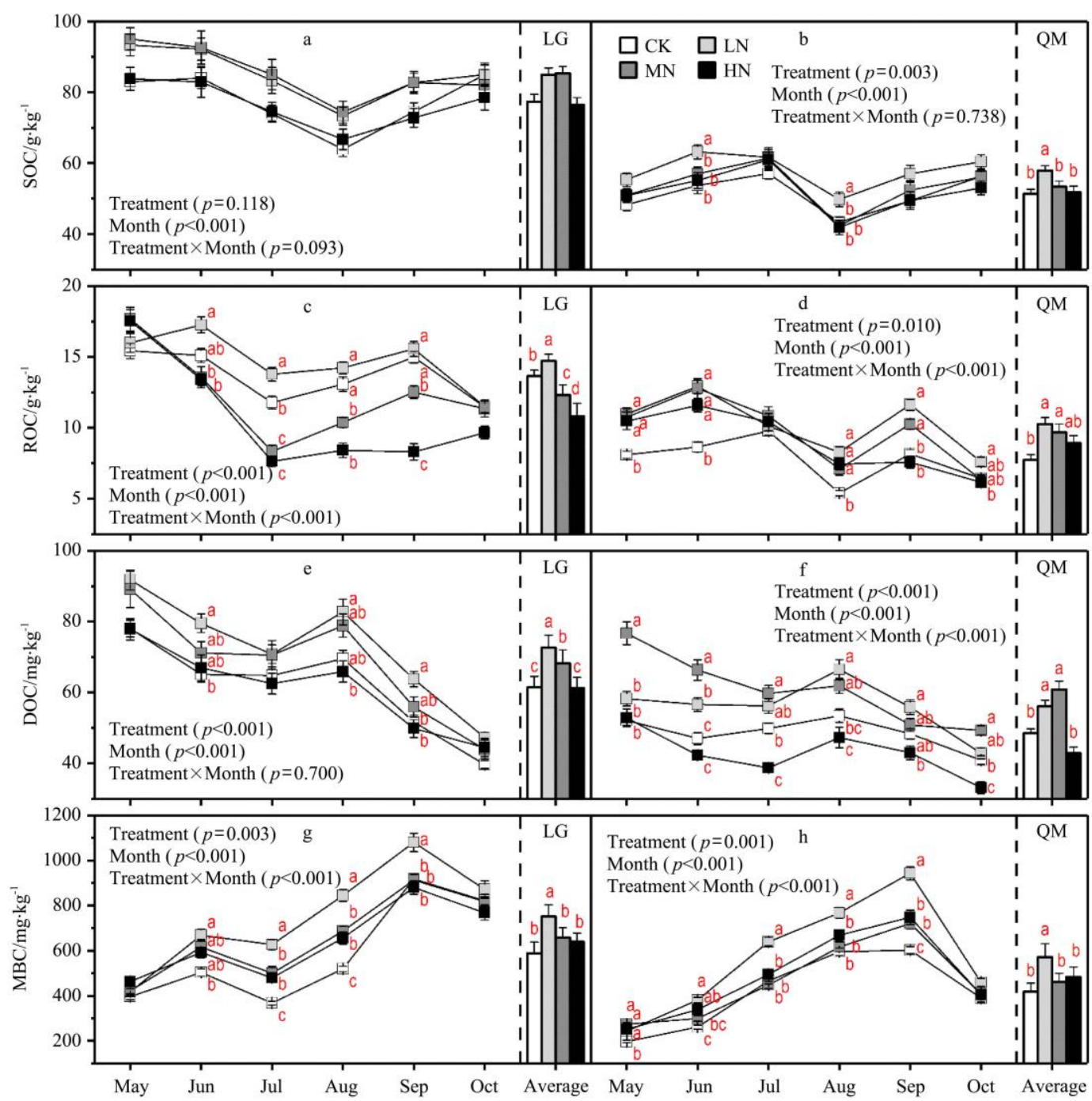

Note: Plots represent the average values of replicates in each month $(n=3)$. Columns represent the average values of all samples in six months $(n=18)$. Error bars represent standard deviations of the means. Results of two-factor mixed-design ANOVAs are shown in the text. Letters indicate significant difference among $\mathrm{N}$ addition treatments ( $p<0.05$, post-hoc Tukey's HSD test).

Figure 2 Variation in soil carbon components under different $\mathrm{N}$ addition from May to October 2017

The responses of proportions of active $\mathrm{C}$ components (ROC/SOC, $\mathrm{DOC} / \mathrm{SOC}$, and $\mathrm{MBC} / \mathrm{SOC})$ to $\mathrm{N}$ addition treatment also showed differences between LG and QM. N addition had a negligible effect on ROC/SOC of QM ( $p=0.177$, Figure $3 b$ ), while MN and HN significantly lowered ROC/SOC of LG ( $p=0.004$, Figure $3 \mathrm{a})$. DOC/SOC of LG was not affected by $\mathrm{N}$ addition ( $p=0.482$, Figure $3 c)$, but $\mathrm{MN}$ increased DOC/SOC of $\mathrm{QM}(p<0.001$, Figure $3 \mathrm{~d})$. Only low level of $\mathrm{N}$ addition raised MBC/SOC of LG ( $p=0.045$, Figure $3 \mathrm{e})$ and $\mathrm{QM}(p=0.003$, Figure $3 \mathrm{f})$. The active $\mathrm{C}$ component proportions showed similar trends over time as their concentrations, due to the relatively smaller variation of SOC compared with active $\mathrm{C}$ components. However, it should be noticed that the active $\mathrm{C}$ component proportions of both LG and QM increased much faster in July compared with their concentrations, which was caused by the decrease of SOC during this month.

\subsection{Effects of $\mathbf{N}$ deposition on soil $\mathbf{N}$ components}

Three-way interaction among $\mathrm{N}$ addition treatment, forest type, and sampling month, as well as two-way interaction between sampling month and forest, was significant for all soil $\mathrm{N}$ components ( $p<0.01$, Table 2 ) and active $\mathrm{N}$ component proportions (DON/STN and MBN/STN) $(p<0.05)$. Sampling month and forest type both had a significant effect on all soil $\mathrm{N}$ components $(p<0.001$, Table 2). STN and active $\mathrm{N}$ components differed between LG and QM $(p<0.001$, Table 2$)$, whereas DON/STN $(p=0.378)$ and $\mathrm{MBN} / \mathrm{STN} \quad(p=0.623)$ had no significant interspecific difference. The average STN, DON, MBN, DON $/ S T N$, and MBN/STN of LG $(6.24 \mathrm{~g} / \mathrm{kg}, 25.0 \mathrm{mg} / \mathrm{kg}$, $133 \mathrm{mg} / \mathrm{kg}, 0.41 \%$, and $2.19 \%$ ) were $1.61,1.57,1.69,0.98$, and 0.99 times the values of $\mathrm{QM}$, respectively. The interaction of forest and $\mathrm{N}$ addition treatment was only significant for DON (Table 2, $p=0.001)$, apart from STN $(p=0.786), \operatorname{MBN}(p=0.671)$, $\operatorname{DON} / \operatorname{STN}(p=0.063)$, and MBN/STN $(p=0.792)$.

$\mathrm{N}$ addition treatment had no significant effect on STN of LG ( $p=0.187$, Figure $4 \mathrm{a}$ ), but increased STN of QM at low and medium levels $(p=0.005$, Figure $4 b$ ). DON of both LG and QM was significantly raised by $\mathrm{N}$ addition treatment (Figures $4 \mathrm{c}$ and $4 \mathrm{~d}$, $p<0.001$ ), and higher level of $\mathrm{N}$ addition led to greater increase in DON. The increase in MBN under $\mathrm{LN}$ was significant for $\mathrm{QM}$ (Figure 4f), but not for LG (Figure 4e).

The monthly variations of STN and MBN were similar to SOC and MBC, respectively (Figures 4a, 4b, 4e, and 4f). A decrease from June to August and an increase from August to October were also found in STN of both LG and QM (Figures 4a and 4b). MBC of QM continuously increased from May to September (Figure 4f), while MBC of LG had a decrease from June to July (Figure 4e). Different trends were observed in DON of LG under $\mathrm{N}$ addition 
treatments. DON of LG under CK and LN showed a decrease in July and an increase in August, which was the opposite of MN and
HN (Figure 4c). DON of QM reached the lowest point in August and increased afterward (Figure 4d).

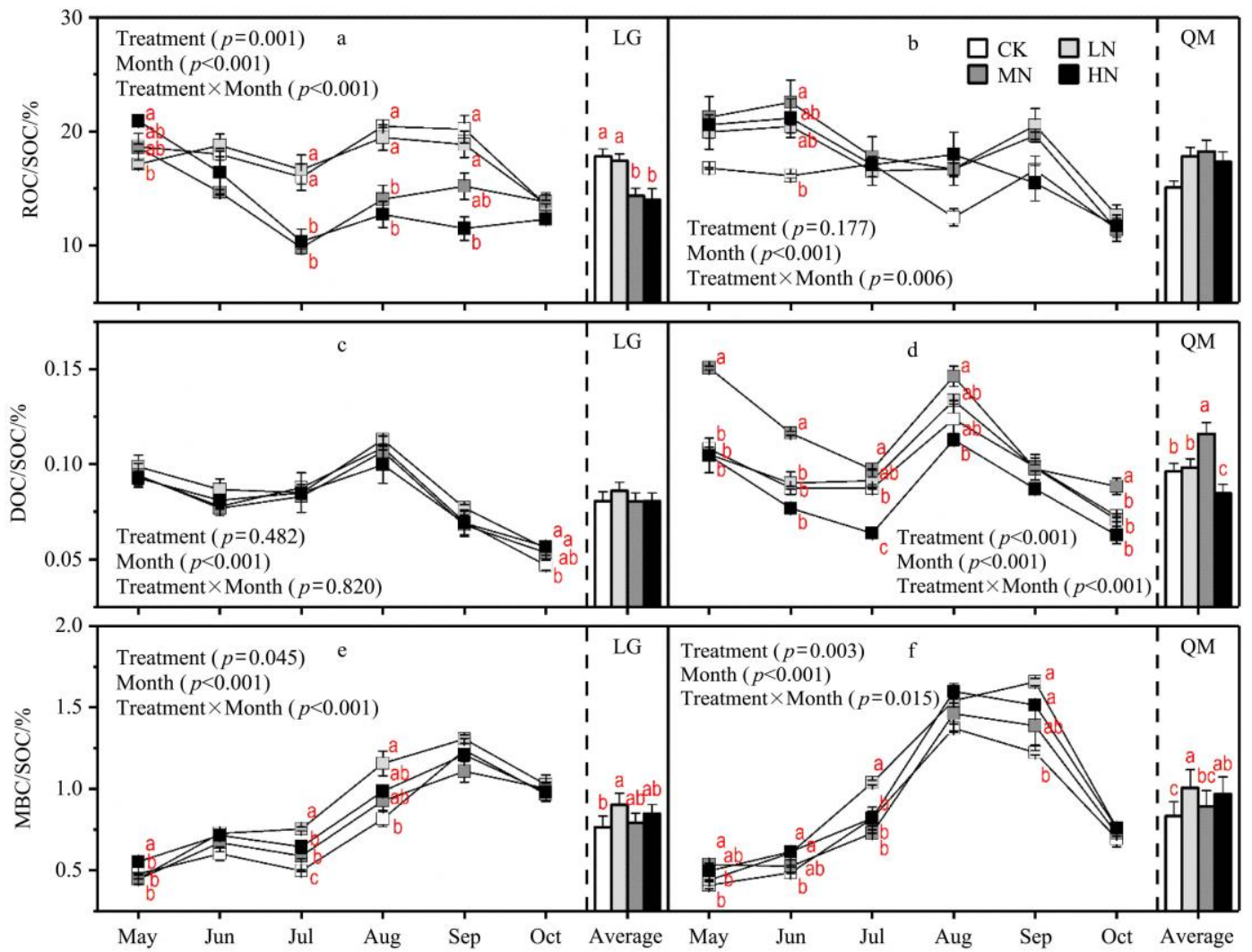

Note: Plots represent the average values of replicates in each month $(n=3)$. Columns represent the average values of all samples in six months $(n=18)$. Error bars represent standard deviations of the means. Results of two-factor mixed-design ANOVAs are shown in the text. Letters indicate significant difference among $\mathrm{N}$ addition treatments ( $p<0.05$, Tukey's HSD test)

Figure 3 Variation in proportions of active soil carbon components under different $\mathrm{N}$ addition from May to October 2017

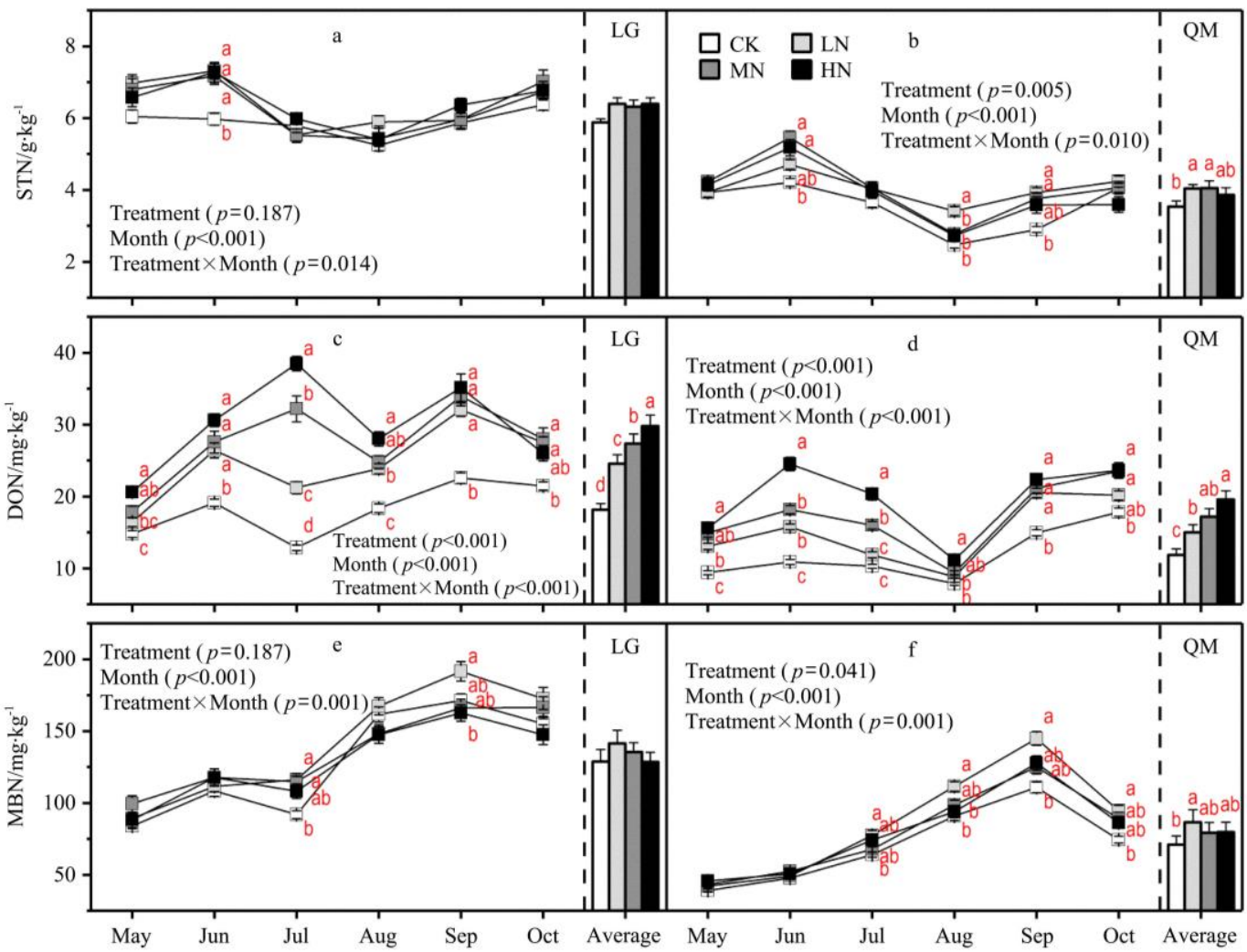

Note: Plots represent the average values of replicates in each month $(n=3)$. Columns represent the average values of all samples in six months $(n=18)$. Error bars represent standard deviations of the means. Results of two-factor mixed-design ANOVAs are shown in the text. Letters indicate significant difference among $\mathrm{N}$ addition treatments $(p<0.05$, post-hoc Tukey's HSD test)

Figure 4 Variation in soil nitrogen components under different $\mathrm{N}$ addition from May to October 2017 
Higher level of $\mathrm{N}$ addition also caused higher DON/STN (Figures $5 \mathrm{a}$ and $5 \mathrm{~b}, p<0.001$ ), except that DON/STN under LN was not significantly higher than $\mathrm{CK}$ (Figure $5 \mathrm{~b}$ ). $\mathrm{N}$ addition negligibly affected MBN/STN of either LG ( $p=0.102$, Figure $5 \mathrm{c})$ or
QM ( $p=0.652$, Figure 5d). MBN/STN of LG and QM showed the same trend over time as $\mathrm{MBC} / \mathrm{SOC}$ (Figures $5 \mathrm{a}$ and $5 \mathrm{~b}$ ), while DON/STN was much different from DOC/SOC (Figures 5c and $5 d)$.

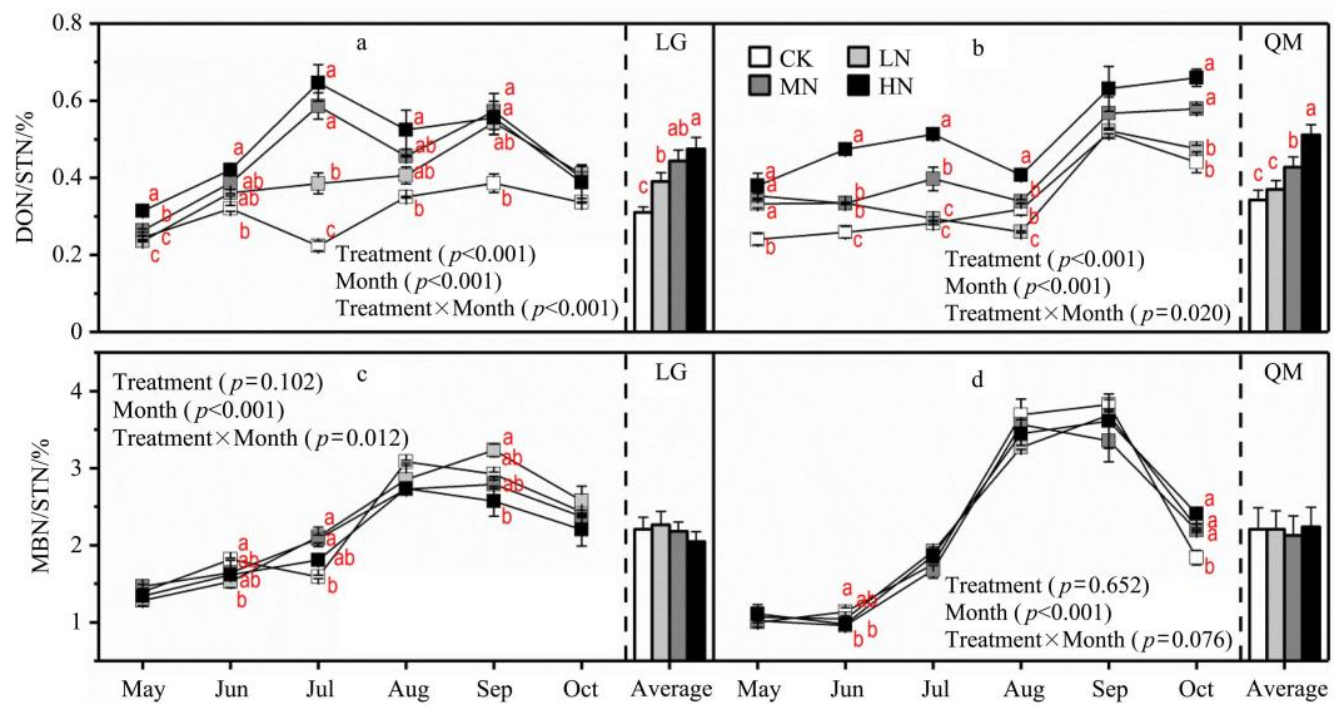

Note: Plots represent the average values of replicates in each month $(n=3)$. Columns represent the average values of all samples in six months $(n=18)$. Error bars represent standard deviations of the means. Results of two-factor mixed-design ANOVAs are shown in the text. Letters indicate significant difference among $\mathrm{N}$ addition treatments ( $p<0.05$, post-hoc Tukey's HSD test).

Figure 5 Variation in proportions of active soil nitrogen components under different $\mathrm{N}$ addition from May to October 2017

\subsection{Effects of $\mathrm{N}$ deposition on $\mathrm{C} / \mathrm{N}$ ratio of soil components}

Sampling month and forest type both had significant effects on $\mathrm{C} / \mathrm{N}$ ratios of soil components $(p<0.001$, Table 2$)$. Interaction of forest type and $\mathrm{N}$ addition was not significant for SOC/STN $(p=0.053)$ and MBC/MBN $(p=0.577)$. The average SOC/STN, DOC/DON, and MBC/MBN of LG across six months (13.1, 4.92, and 2.92) were $0.92,0.80$, and 0.77 times as much as QM, respectively.

$\mathrm{N}$ Addition had no effect on SOC/STN ( $p=0.167$, Figure 6a) and MBC/MBN of LG $(p=0.077$, Figure $6 \mathrm{e})$. MN and HN decreased SOC/STN of QM ( $p<0.001$, Figure $6 \mathrm{~b})$, while LN and $\mathrm{HN}$ increased $\mathrm{MBC} / \mathrm{MBN}$ of $\mathrm{QM}(p<0.001$, Figure $6 \mathrm{f})$. DOC/DON of LG and QM significantly declined with the elevated level of $\mathrm{N}$ addition (Figures $6 \mathrm{c}$ and $6 \mathrm{~d}$ ).

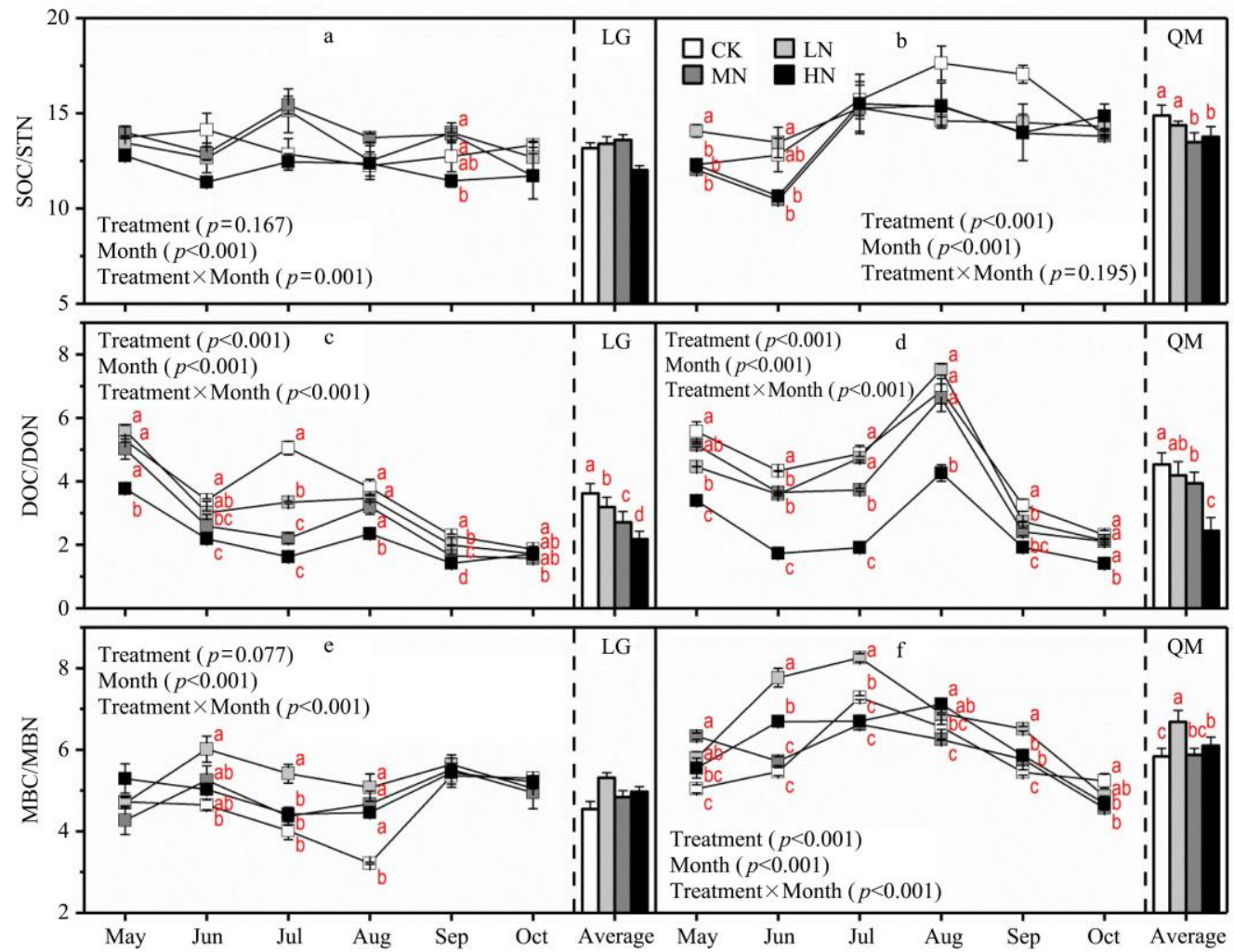

Note: Plots represent the average values of replicates in each month $(n=3)$. Columns represent the average values of all samples in six months $(n=18)$. Error bars represent standard deviations of the means. Results of two-factor mixed-design ANOVAs are shown in text. Letters indicate significant difference among $\mathrm{N}$ addition treatments $(p<0.05$, post-hoc Tukey's HSD test).

Figure 6 Effect of $\mathrm{N}$ deposition on $\mathrm{C} / \mathrm{N}$ ratio of different soil components in two forest soils 


\subsection{Relationships between soil components and environmental} factors

RDA was carried out for two forest types (LG and QM) using soil $\mathrm{C}$ and $\mathrm{N}$ component concentrations with $\mathrm{N}$ addition treatments and sampling month as dummy variables (Figure 7). A highly significant positive correlation was observed between SOC and STN, as well as between MBC and MBN, and between ROC and DOC, in both LG and QM stands. DON showed a negative

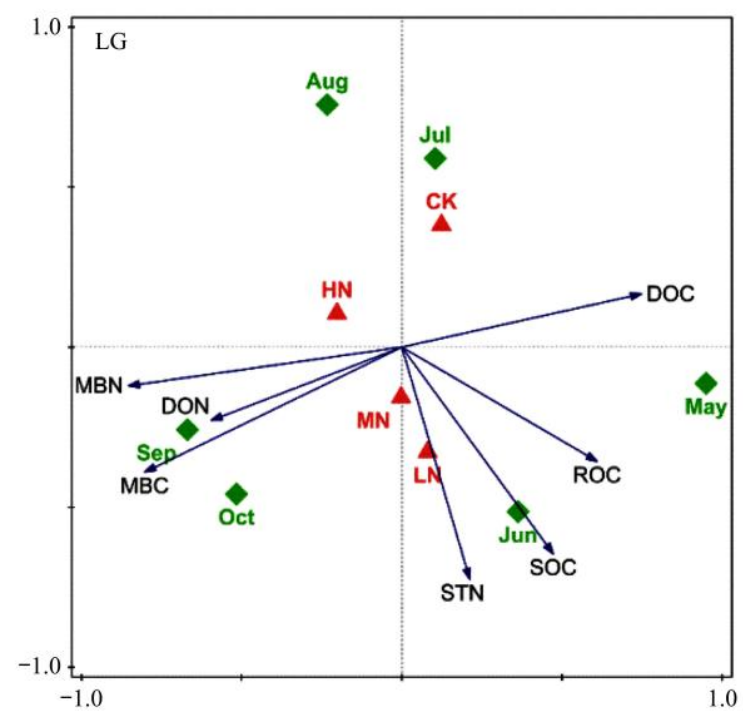

relationship with DOC in both LG and QM. Among $\mathrm{N}$ addition treatments, LN had the largest influence on SOC and STN, followed by MN. HN showed a negative influence on DOC but a strong positive correlation with DON. CK was in the opposite direction of increase for SOC and STN. SOC was linked to Jun in LG and Jul in QM. MBC and MBN were strongly related to Sep. Aug had a long negative projection distance from SOC, ROC, and STN.

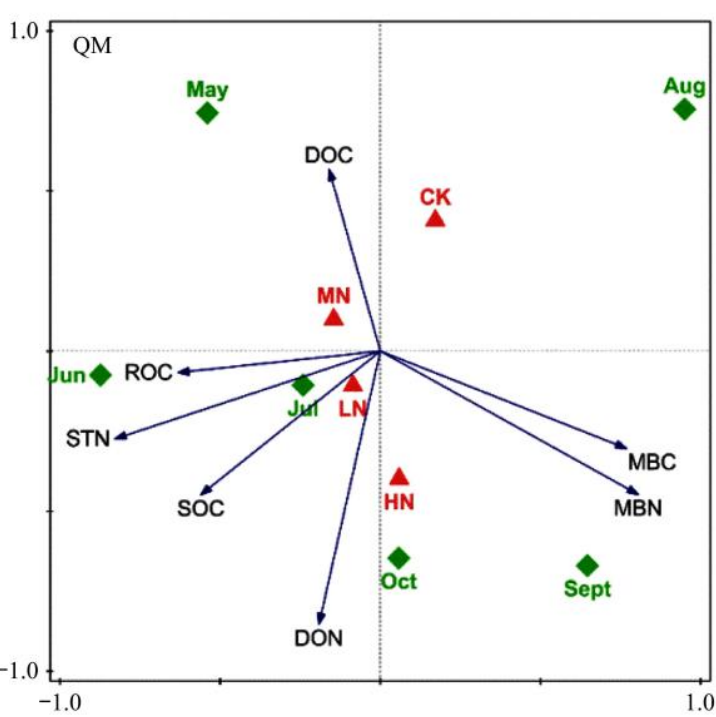

Note: $n=72$, i.e. four $\mathrm{N}$ addition levels $\times$ six months $\times$ three repeats. Arrow lengths indicate the strength of the relationship between the soil properties and the environmental factors. The direction of the line indicates the direction of increase for a specific soil property.

Figure 7 Redundancy analysis (RDA) of soil components of two forest types with N addition treatments and sampling months

\section{Discussion}

This study intended to determine how soil $\mathrm{C}$ and $\mathrm{N}$ components, including SOC, STN, and their active fractions, respond to a short-term simulated $\mathrm{N}$ deposition in LG and QM plantations. The results showed divergent responses of soil $\mathrm{C}$ and $\mathrm{N}$ under different levels of $\mathrm{N}$ addition between the two forest types. $\mathrm{N}$ addition had no effect on SOC and STN of LG, but significantly increased SOC and STN of QM at low N addition level. Active C and $\mathrm{N}$ components showed higher sensitivity to $\mathrm{N}$ addition and sampling month. Low level of $\mathrm{N}$ addition generally raised active $\mathrm{C}$ components (ROC, DOC, and $\mathrm{MBC}$ ) in both plantations, whereas high $\mathrm{N}$ addition did not significantly affect these components, or even decreased ROC in LG soil. Low $\mathrm{N}$ addition also increased STN and MBN of QM, while no significant change in STN and MBN of LG was observed. DON was directly affected by $\mathrm{N}$ addition and increased significantly with elevated $\mathrm{N}$ addition levels.

The result that SOC and STN of LG had negligible change under $\mathrm{N}$ addition is consistent with the results reported by previous studies on larch (Larix spp.) plantation in Northeast China ${ }^{[15,41]}$, and different forest types in other regions ${ }^{[25,42]}$. The change in soil total $\mathrm{C}$ generally reflects the balance between $\mathrm{C}$ inputs of primary production and $\mathrm{C}$ outputs from soil respiration ${ }^{[41]}$. The absence of change in SOC and STN of LG under N addition might be caused by the decrease in fine root biomass which can inhibit soil $\mathrm{C}$ sequestration ${ }^{[43]}$, or by the counteraction of $\mathrm{C}$ or $\mathrm{N}$ in light and heavy soil fractions which might be affected differently by $\mathrm{N}$ $\operatorname{addition}^{[19]}$.

In contrast, $\mathrm{N}$ addition increased organic $\mathrm{C}$ pools in surface soils of QM, which agrees with several previous studies in China ${ }^{[44-46]}$. $\mathrm{N}$ is often the limiting nutrient in Northeast China, low levels of $\mathrm{N}$ addition generally increase plant production and the accumulation of soil organic matter, thus increasing the forest $\mathrm{C}$ sequestration ${ }^{[47]}$. Furthermore, it should be noted that SOC of QM under LN treatment was significantly higher than CK only in June and August, which belongs to summer with high temperature, while STN of QM under LN treatment showed significance only in June, August, and September. In summer, higher temperatures can enhance microbial growth ${ }^{[48]}$.

ROC and DOC are important active C components, mainly derived from root secretion and microbial action ${ }^{[49]}$. N addition affects ROC and DOC by influencing tree root growth and microbial biomass. In this study, a significant difference was observed in ROC, MBC, and DOC between two forest types, which was consistent with previous studies, indicating that $\mathrm{N}$ deposition led to a significant increase of DOC in hardwood, but non-significant increase in pine ${ }^{[50]}$. The rise of DOC under $\mathrm{N}$ addition treatments in this study was consistent with previous studies which reported that $\mathrm{N}$ addition increased DOC in tropical forests ${ }^{[51]}$ and temperate forests ${ }^{[52]}$. However, some others observed a reduction in DOC by $\mathrm{N}$ addition ${ }^{[53,54]}$. These conflicting results could be due to the differences in climatic zones, forest types, soil texture, $\mathrm{pH}$, as well as the types and amounts of fertilizers used. Our results suggested that the concentration of DOC and ROC showed an increasing tendency first and then decreasing with the increase of $\mathrm{N}$ addition, which was consistent with McDowell's study ${ }^{[55]}$. The reason could be that $\mathrm{LN}$ treatment had little affection for root biomass and increased the soil microbial biomass. Thus the HN treatment significantly reduced the root biomass and the microbial biomass.

$\mathrm{C} / \mathrm{N}$ ratio is a key factor for microorganisms to decompose litters and soil organic matter ${ }^{[56]}$. It was positively related to the leaching of DOC in topsoil $(5-40 \mathrm{~cm})$. High $\mathrm{C} / \mathrm{N}$ ratio enhances 
microbial activity and produces more soluble products ${ }^{[57]}$. In this study, $\mathrm{N}$ addition reduced the $\mathrm{C} / \mathrm{N}$ ratio, which could suppress the generation and leaching of DOC and increase the $\mathrm{C}$ storage in soil.

Soil microorganisms are important indicators of soil $\mathrm{C}$ pools, and they significantly affect the soil $\mathrm{C}$ cycle ${ }^{[58,59]}$. In this study, $\mathrm{N}$ deposition significantly increased MBC (Figure 2, $p<0.001$ ), whereas some studies concluded that $\mathrm{N}$ deposition would reduce microbial ${ }^{[60,61]}$. The reason could be that the duration of this experiment is short, and the $\mathrm{N}$ deposition alleviates the carbon limitation of soil microorganisms by promoting net primary production and producing more litters. At the same time, the $\mathrm{C} / \mathrm{N}$ ratio of litters might be changed to provide a better substrate for microorganisms. A tendency of MBC increased by $\mathrm{N}$ addition treatment was found, which could be caused by $\mathrm{N}$ limitation. The decrease of $\mathrm{MBC}$ along with the increase of $\mathrm{N}$ deposition indicated a restriction on soil microbes under $\mathrm{HN}$ treatment. MBC achieved the maximum concentration in September, which was because that the soil microbial biomass gradually increased with a temperature rising $^{[62]}$, and the amount of available nutrients for soil microbes reached the highest in autumn due to the increase of plant litter.

Low $\mathrm{N}$ addition increased STN, which could be due to the more leaf litter and the increase in soil microbial $\mathrm{N}$ fixation, while $\mathrm{HN}$ treatment exceeded the threshold of microbial demand, and at the same time, HN treatment could promote nitration and the higher $\mathrm{N}$ leaching ${ }^{[63]}$. All treatments significantly increased DON content, indicating that the probability of $\mathrm{N}$ loss increased with the increase of $\mathrm{N}$ deposition ${ }^{[64]}$. In this study, DON showed a negative relationship with DOC in both LG and QM, which was different from the results obtained in a Larix principis-rupprechtii plantation in Northern China ${ }^{[65]}$.

\section{Conclusions}

The results suggested that $\mathrm{N}$ addition treatments increased soil C storage, including SOC and active component contents, with a tendency of increasing first and then decreasing by the increase of $\mathrm{N}$ addition. These contents in LG were significantly higher than in QM. LN treatment significantly increased MBC, DOC, and ROC of QM. MN treatment significantly increased ROC and DOC of LG. HN treatment increased ROC in LG and DOC in QM. STN and its active components in LG were significantly higher than in QM, LN and HN treatments. STN, DON in LN treatment in LG and STN in LN and MN treatment in QM were significantly higher than CK. All $\mathrm{N}$ addition treatment raised DON in QM significantly. Furthermore, $\mathrm{N}$ addition reduced the $\mathrm{C} / \mathrm{N}$ ratio, especially in $\mathrm{QM}$.

$\mathrm{N}$ deposition became an issue of global attention, and its impact on forest soil carbon pools could play an important role in global change. Therefore, the accurate assessment of such influence on soil carbon pools is critical for developing climate change targets and mitigation policies. Our results suggested that the low $\mathrm{N}$ deposition could be effective in addressing the global change, but the effect could be weakened with the increase of $\mathrm{N}$ deposition ratio. This study was conducted in two forest types, comprised of four $\mathrm{N}$ deposition levels and covered a whole growing season. Due to the different responses among forest types, stand ages, duration of experiments, long-term simulated experiments and more subjects should be considered in future works.

\section{Acknowledgements}

This work was supported by the National Key Research and
Development Program of China (grant No. 2016YFD0200304, 2017YFC0504205).

\section{[References]}

[1] Galloway J N, Townsend A R, Erisman J W, Bekunda M, Cai Z C, Freney J $\mathrm{R}$, et al. Transformation of the nitrogen cycle: Recent trends, questions, and potential solutions. Science, 2008; 320(5878): 889-892.

[2] Niu S L, Classen A T, Dukes J S, Kardol P, Liu L L, Luo Y Q, et al Global patterns and substrate-based mechanisms of the terrestrial nitrogen cycle. Ecol Lett., 2016; 19(6): 697-709.

[3] Dirnbock T, Foldal C, Djukic I, Kobler J, Haas E, Kiese R, et al. Historic nitrogen deposition determines future climate change effects on nitrogen retention in temperate forests. Clim Change, 2017; 144(2): 221-35.

[4] Law B. Biogeochemistry: Nitrogen deposition and forest carbon Nature, 2013; 496(7445): 307-308.

[5] Canadell J G, Raupach M R. Managing forests for climate change mitigation. Science, 2008; 320(5882): 1456-1457.

[6] Cleveland C C, Townsend A R. Nutrient additions to a tropical rain forest drive substantial soil carbon dioxide losses to the atmosphere. Proc Natl Acad Sci USA, 2006; 103(27): 10316-10321.

[7] Fornara D A, Tilman D. Soil carbon sequestration in prairie grasslands increased by chronic nitrogen addition. Ecology, 2012; 93(9): 2030-2036.

[8] Comeau LP, Hergoualc'h K, Hartill J, Smith J, Verchot L V, Peak D, et al. How do the heterotrophic and the total soil respiration of an oil palm plantation on peat respond to nitrogen fertilizer application? Geoderma, 2016; 268: 41-51.

[9] Mack M C, Schuur E A G, Bret-Harte M S, Shaver G R, Chapin F S Ecosystem carbon storage in arctic tundra reduced by long-term nutrient fertilization. Nature, 2004; 431(7007): 440-443.

[10] Mo J, Zhang W, Zhu W, Gundersen P, Fang Y, Li D, et al. Nitrogen addition reduces soil respiration in a mature tropical forest in southern China. Glob Change Biol., 2008; 14(2): 403-412.

[11] Sun Z Z, Liu L L, Ma Y C, Yin G D, Zhao C, Zhang Y, et al. The effect of nitrogen addition on soil respiration from a nitrogen-limited forest soil. Agric For Meteorol, 2014; 197: 103-110.

[12] Zeng D H, Li L J, Fahey T J, Yu Z Y, Fan Z P, Chen F S. Effects of nitrogen addition on vegetation and ecosystem carbon in a semi-arid grassland. Biogeochemistry, 2010; 98(1-3): 185-193.

[13] Wei D, Xu R, Liu Y W, Wang Y H, Wang Y S. Three-year study of $\mathrm{CO}_{2}$ efflux and $\mathrm{CH}_{4} / \mathrm{N}_{2} \mathrm{O}$ fluxes at an alpine steppe site on the central Tibetan Plateau and their responses to simulated $\mathrm{N}$ deposition. Geoderma, 2014; 232: 88-96.

[14] Vourlitis G L, Hentz C S. Impacts of chronic N input on the carbon and nitrogen storage of a postfire Mediterranean-type shrubland. Journal of Geophysical Research-Biogeosciences, 2016; 121(2): 385-398.

[15] Hu Y L, Zeng D H, Liu Y X, Zhang Y L, Chen Z H, Wang Z Q. Responses of soil chemical and biological properties to nitrogen addition in a Dahurian larch plantation in Northeast China. Plant Soil, 2010; 333(1-2): 81-92.

[16] Tian D, Du E Z, Jiang L, Ma S H, Zeng W J, Zou A L, et al. Responses of forest ecosystems to increasing $\mathrm{N}$ deposition in China: A critical review. Environ Pollut, 2018; 243: 75-86.

[17] Evans C, Goodale C, Caporn S, Dise N, Emmett B, Fernandez I, et al. Does elevated nitrogen deposition or ecosystem recovery from acidification drive increased dissolved organic carbon loss from upland soil? A review of evidence from field nitrogen addition experiments. Biogeochemistry, 2008; 91(1): 13-35.

[18] Bobbink R, Hicks K, Galloway J, Spranger T, Alkemade R, Ashmore M, et al. Global assessment of nitrogen deposition effects on terrestrial plant diversity: A synthesis. Ecol Appl., 2010; 20(1): 30-59.

[19] Neff J C, Townsend A R, Gleixner G, Lehman S J, Turnbull J, Bowman W D. Variable effects of nitrogen additions on the stability and turnover of soil carbon. Nature, 2002; 419(6910): 915-917.

[20] Sedjo R A. The carbon cycle and global forest ecosystem. Water Air Soil Pollut, 1993; 70(1-4): 295-307.

[21] Haynes R J. Labile organic matter fractions as central components of the quality of agricultural soils: An overview. In: Sparks DL, editor. Advances in Agronomy, Vol 85. Advances in Agronomy. 85. San Diego: Elsevier Academic Press Inc, 2005; pp.221-268.

[22] Davidson E A, Janssens I A. Temperature sensitivity of soil carbon decomposition and feedbacks to climate change. Nature, 2006; 440(7081) 
$165-173$.

[23] Wander M M, Traina S J, Stinner B R, Peters S E. Organic and conventional management effects on biologically active soil organic matter pools. Soil Sci Soc Am J., 1994; 58(4): 1130-1139.

[24] Coleman D C, Reid C P P, Cole CV. Biological strategies of nutrient cycling in soil systems. Adv Ecol Res., 1983; 13: 1-55.

[25] Chen X M, Liu J X, Deng Q, Yan J H, Zhang D Q. Effects of elevated $\mathrm{CO}_{2}$ and nitrogen addition on soil organic carbon fractions in a subtropical forest. Plant Soil, 2012; 357(1-2): 25-34.

[26] Blair G J, Lefroy R D B, Lise L. Soil carbon fractions based on their degree of oxidation, and the development of a carbon management index for agricultural systems. Aust J Agric Res., 1995; 46(7): 1459-1466.

[27] Plante A F, Fernandez J M, Haddix M L, Steinweg J M, Conant R T. Biological, chemical and thermal indices of soil organic matter stability in four grassland soils. Soil Biol Biochem., 2011; 43(5): 1051-1058.

[28] Franzluebbers A J, Arshad M A. Particulate organic carbon content and potential mineralization as affected by tillage and texture. Soil Sci Soc Am J, 1997; 61(5): 1382-1386.

[29] Chen C R, Xu Z H. Analysis and behavior of soluble organic nitrogen in forest soils. J Soils Sediments, 2008; 8(6): 363-378.

[30] Ross D J, Speir T W, Kettles H A, Mackay A D. Soil microbial biomass, $\mathrm{C}$ and $\mathrm{N}$ mineralization and enzyme activities in a hill pasture: Influence of season and slow-release P and S fertilizer. Soil Biol Biochem., 1995; 27(11): 1431-1443.

[31] Erisman J W, Galloway J, Seitzinger S, Bleeker A, Butterbach-Bahl K. Reactive nitrogen in the environment and its effect on climate change. Curr Opin Environ Sustain, 2011; 3(5): 281-290.

[32] Gielen B, Neirynck J, Luyssaert S, Janssens I A. The importance of dissolved organic carbon fluxes for the carbon balance of a temperate Scots pine forest. Agric For Meteorol., 2011; 151(3): 270-278.

[33] Vet R, Artz R S, Carou S, Shaw M, Ro C U, Aas W, et al. A global assessment of precipitation chemistry and deposition of sulfur, nitrogen, sea salt, base cations, organic acids, acidity and $\mathrm{pH}$, and phosphorus. Atmos Environ., 2014; 93: 3-100.

[34] Liu X J, Zhang Y, Han W X, Tang A H, Shen J L, Cui Z L, et al. Enhanced nitrogen deposition over China. Nature, 2013; 494(7438): 459-462.

[35] Fang J Y, Yu G R, Liu L L, Hu S J, Chapin F S. Climate change, human impacts, and carbon sequestration in China. Proc Natl Acad Sci USA, 2018; 115(16): 4015-4020.

[36] Zhu J X, He N P, Wang Q F, Yuan G F, Wen D, Yu G R, et al. The composition, spatial patterns, and influencing factors of atmospheric wet nitrogen deposition in Chinese terrestrial ecosystems. Sci Total Environ, 2015; 511: 777-785.

[37] Mo J M, Brown S, Xue J, Fang Y, Li Z. Response of litter decomposition to simulated $\mathrm{N}$ deposition in disturbed, rehabilitated and mature forests in subtropical China. Plant Soil, 2006; 282(1-2): 135-151.

[38] Wu J, Joergensen R G, Pommerening B, Chaussod R, Brookes P C. Measurement of soil microbial biomass $\mathrm{C}$ by fumigation-extraction-An automated procedure. Soil Biol Biochem., 1990; 22(8): 1167-1169.

[39] Brookes P C, Landman A, Pruden G, Jenkinson D S. Chloroform fumigation and the release of soil nitrogen: A rapid direct extraction method to measure microbial biomass nitrogen in soil. Soil Biol Biochem., 1985; 17(6): 837-842.

[40] Boyer J N, Groffman P M. Bioavailability of water extractable organic carbon fractions in forest and agricultural soil profiles. Soil Biol Biochem., 1996; 28(6): 783-790.

[41] Yang K, Zhu J J, Gu J C, Xu S, Yu L Z, Wang Z Q. Effects of continuous nitrogen addition on microbial properties and soil organic matter in a Larix gmelinii plantation in China. J For Res., 2018; 29(1): 85-92.

[42] Scheuner E T, Makeschin F. Impact of atmospheric nitrogen deposition on carbon dynamics in two Scots pine forest soils of Northern Germany. Plant Soil, 2005; 275(1-2): 43-54.

[43] Jia S X, Wang Z Q, Li X P, Sun Y, Zhang X P, Liang A Z. N fertilization affects on soil respiration, microbial biomass and root respiration in Larix gmelinii and Fraxinus mandshurica plantations in China. Plant Soil, 2010; 333(1-2): 325-336.

[44] Huang Z Q, Clinton P W, Baisden W T, Davis M R. Long-term nitrogen additions increased surface soil carbon concentration in a forest plantation despite elevated decomposition. Soil Biol Biochem., 2011; 43(2):
302-307.

[45] Chen X M, Li Y L, Mo J M, Otieno D, Tenhunen J, Yan J H, et al. Effects of nitrogen deposition on soil organic carbon fractions in the subtropical forest ecosystems of S China. J Plant Nutr Soil Sci., 2012; 175(6): 947-953.

[46] Yan G Y, Xing Y J, Xu L J, Wang J Y, Meng W, Wang Q G, et al Nitrogen deposition may enhance soil carbon storage via change of soil respiration dynamic during a spring freeze-thaw cycle period. Sci Rep., 2016; 6:9.

[47] Yan G Y, Xing Y J, Wang J Y, Li Z H, Wang L G, Wang Q G, et al Sequestration of atmospheric $\mathrm{CO}_{2}$ in boreal forest carbon pools in northeastern China: Effects of nitrogen deposition. Agric for Meteorol, 2018; 248: 70-81.

[48] Edwards K A, McCulloch J, Kershaw G P, Jefferies R L. Soil microbia and nutrient dynamics in a wet Arctic sedge meadow in late winter and early spring. Soil Biol Biochem., 2006; 38(9): 2843-2851.

[49] Jiang Y M, Chen C R, Liu Y Q, Xu Z H. Soil soluble organic carbon and nitrogen pools under mono- and mixed species forest ecosystems in subtropical China. J Soils Sediments, 2010; 10(6): 1071-1081.

[50] Yano Y, McDowell W H, Aber J D. Biodegradable dissolved organic carbon in forest soil solution and effects of chronic nitrogen deposition. Soil Biol Biochem., 2000; 32(11-12): 1743-17451.

[51] Cusack D F, Silver W L, Torn M S, McDowell W H. Effects of nitrogen additions on above- and belowground carbon dynamics in two tropical forests. Biogeochemistry, 2011; 104(1-3): 203-225.

[52] Pregitzer K S, Zak D R, Burton A J, Ashby J A, MacDonald N W. Chronic nitrate additions dramatically increase the export of carbon and nitrogen from northern hardwood ecosystems. Biogeochemistry, 2004; 68(2): 179-197.

[53] Park J-H, Kalbitz K, Matzner E. Resource control on the production of dissolved organic carbon and nitrogen in a deciduous forest floor. Soil Biology and Biochemistry, 2002; 34(6): 813-822.

[54] Vestgarden L S, Abrahamsen G, Stuanes A O. Soil solution response to nitrogen and magnesium application in a Scots pine forest. Soil Science Society of America Journal, 2001; 65(6): 1812-1823.

[55] McDowell W H, Currie W S, Aber J D, Yang Y. Effects of chronic nitrogen amendments on production of dissolved organic carbon and nitrogen in forest soils. Biogeochemical Investigations at Watershed, Landscape, and Regional Scales: Springer, 1998; pp.175-182.

[56] Meng L, Zhou X, Luo Y, Yang Y, Fang C, Chen J, et al. Minor stimulation of soil carbon storage by nitrogen addition: A meta-analysis. Agriculture Ecosystems \& Environment, 2011; 140(1-2): 234-244.

[57] Kindler R, Siemens J, Kaiser K, Moors E J. Dissolved carbon leaching from soil is a crucial component of the net ecosystem carbon balance. Global Change Biology, 2011; 17(2): 1167-1185.

[58] Cusack D F, Torn M S, Mcdowell W H, Silver W L. The response of heterotrophic activity and carbon cycling to nitrogen additions and warming in two tropical soils. Global Change Biology, 2010; 16(9): 2555-2572.

[59] Wardle D A, Bardgett R D, Klironomos J N, Heikki S L, Putten W H, Van Der Wall D H. Ecological linkages between aboveground and belowground biota. Science, 2004; 304(5677): 1629-1633.

[60] Treseder K K. Nitrogen additions and microbial biomass: a meta-analysis of ecosystem studies. Ecology Letters, 2010; 11(10): 1111-1120.

[61] Zhang T, Chen H Y H, Ruan H. Global negative effects of nitrogen deposition on soil microbes. The ISME Journal, 2018; 12(7): 1817-18125.

[62] Turner M M, Henry H A L. Interactive effects of warming and increased nitrogen deposition on $15 \mathrm{~N}$ tracer retention in a temperate old field. Global Change Biology, 2010; 15(12): 2885-2893.

[63] Gundersen P, Emmett B A, Kjønaas O J, Koopmans C J, Tietema A. Impact of nitrogen deposition on nitrogen cycling in forests: A synthesis of NITREX data. Forest Ecology \& Management, 1998; 101(1-3): 37-55.

[64] Howarth R W, Billen G, Swaney D, Townsend A, Jaworski N, Lajtha K, et al. Regional nitrogen budgets and riverine $\mathrm{N} \& \mathrm{P}$ fluxes for the drainages to the North Atlantic Ocean: Natural and human influences. Biogeochemistry, 1996; 35(1): 75-139.

[65] Ma J Y, Kang F F, Cheng X Q, Han H R. Response of soil organic carbon and nitrogen to nitrogen deposition in a Larix principis-rupprechtii plantation. Sci Rep., 2018; 8: 10. 